\title{
HUBUNGAN KECERDASAN EMOSI DENGAN KEMAMPUAN BERSOSIALISASI SISWA DI LINGKUNGAN SEKOLAH KELAS VII SMP NEGERI 03 MUKOMUKO
}

\author{
Deska Herlinda, Wasidi, Illawaty Sulian \\ Program Studi Bimbingan dan Konseling Fakultas Keguruan dan Ilmu Pendidikan \\ Universitas Bengkulu \\ deska.herlinda0123@gmail.com,wasidirma@unib.ac.id,illawaty@unib.ac.id
}

\begin{abstract}
ABSTRAK
Penelitian ini bertujuan untuk mengetahui hubungankecerdasan emosi dengan kemampuan siswa dalam bersosialisasi di lingkungan sekolah kelas VII SMP NEGERI 03 Mukomuko. Sampel penelitian berjumlah 99 orang siswa yang diambil dengan teknik clusters random sampling dari seluruh kelas VII. Metode penelitian ini adalah penelitian deskriptif kuantitatif dengan teknik korelasi. Instrumen yang digunakan dalam penelitian ini adalah kuesioner kecerdasan emosi dan bersosialisasi. Data dianalisis dengan menggunakan korelasi product moment Pearson. Hasil penelitian menunjukkan kecerdasan emosi yang dimiliki siswa termasuk ke dalam kategori sedang dengan presentase $60 \%$ dan bersosialisasi yang dimiliki juga termasuk ke dalam kategori sedang dengan presentase $50 \%$. Hasil penelitian menunjukkan adanya hubungan positif yang signifikan antara kecerdasan emosi dengan kemampuan bersosialisasi dengan $r_{x y}$ sebesar 0,426. Hal ini menunjukkan bahwa H0 ditolak dan Ha diterima.
\end{abstract}

Kata kunci: kecerdasan emosi, kemampuan bersosialisasi

THE CORRELATION BETWEEN STUDENTS' EMOTIONAL INTELLIGENCE AND THEIR SOCIALIZATION ABILITY IN SCHOOL ENVIRONMENT ONE FIRST GRADE SMPN 03 MUKOMUKO

\begin{abstract}
This research aimed to know the relation of the correlation between students emotional intelligence and their socialization ability in School environment one first grade SMPN 03 mukomuko. These samples are 99 students were taken using clusters random sampling technique. The research of this study was under the term of descriptive quantitative method with correlation technique. The instrument used in this research was questionnaire of emotional intelligence and socialization ability. The data was analyzed by using product moment correlation of pearson. The result of this research has shown that the students with moderate emotional intelligence were $60 \%$ and socialization ability that they have in moderate category were $50 \%$. The result showed that a significant positive correlation between emotional intelligence and socialization ability with $r_{x y}$ of 0,426. This showed that $\mathrm{HO}$ is rejected and Ha received.
\end{abstract}

Keywords : emotional intelligence, socialization ability 


\section{Pendahuluan}

Menurut Munandar (2009:6), pendidikan mempunyai peranan yang sangat menetukan bagi perkembangan dan perwujudan diri individu, terutama bagi pembangunan bangsa dan negara. Kemajuan suatu kebudayaan bergantung kepada cara seseorang tersebut mengenali, menghargai, dan memanfaatkan sumber daya manusia dan hal ini berkaitan erat dengan kualitas pendidikan yang diberikan kepada masyarakat maupun peserta didik.

Menurut Danim (2010:5-6), guru adalah pendidik profesional dengan tugas utama mendidik, mengajar, membimbing, mengarahkan, melatih, menilai, dan mengevaluasi peserta didik pada jalur pendidikan formal. Kedudukan guru sebagai tenaga profesional bertujuan untuk melaksanakan sistem pendidikan nasional dan mewujudkan tujuan pendidikan nasional, yaitu berkembangnya potensi peserta didik agar menjadi manusia yang beriman dan bertaqwa kepada Tuhan Yang Maha Esa, berakhlak mulia, sehat, berilmu, cakap, kreatif, mandiri, serta menjadi warga negara yang demokratis dan bertanggung jawab.

Seha (2013), menjelaskan bahwa untuk mewujudkan tujuan pendidikan tersebut, tentunya tak mudah karena tantangan dan permasalahan di segala bidang pendidikan selalu timbul dengan adanya globalisasi, informasi, dan teknologi, padahal tidak mudah untuk menghentikan gelombang perubahan yang diakibatkan oleh semangat globalisasi dan derasnya arus informasi yang melanda dunia itu dan bahkan tidak ada alasan untuk mencegahnya. Era globalisasi sudah berada di hadapan kita, gelombang perubahan telah mulai, perubahan semakin besar akan segera datang.

Mutamminah (2014), menjelaskan bahwa manusia disebut sebagai makhluk monodualisme. Hal ini karena selain berperan sebagai makhluk individual, manusia juga merupakan makhluk sosial. Sebagai makhluk sosial manusia dituntut untuk mengatasi permasalahan yang timbul sebagai hasil interaksi dengan lingkungan sosial dan mampu menampilkan diri sesuai dengan aturan atau norma yang berlaku. Oleh karena itu setiap manusia dituntut untuk menguasai keterampilan sosial untuk menyesuaikan diri dengan lingkungan. 
Menurut Goleman (1995: 44), IQ hanya menyumbang sebesar 20\% dalam mencapai kesuksesan seseorang, sedangkan 80\% lainnya adalah sumbangan faktor-faktor kekuatan lain, yaitu bakat, kecerdasan emosional, faktor biologis, dan faktor sosial lingkungan. Sedangkan Susiani (2013) menjelaskan bahwa kecerdasan sosio-emosional merupakan kemampuan individu untuk memahami, mengenali dan mengendalikan kondisi emosi dirinya dan orang lain agar mampu berinteraksi dengan baik terhadap lingkungan sosialnya. Kenyataan di lapangan menunjukkan banyak siswa kita menunjukkan rendahnya kecerdasan sosioemosional, diantaranya adalah sikap egois, suka menang sendiri, tidak menghargai orang lain, dan tidak peduli kesusahan orang lain.

Nasution (2003), menyatakan bahwa di dalam diri manusia banyak emosi dengan berbagai bentuk ungkapan seperti: marah, sedih, senang, cinta, bahagia, dan sebagainya. Emosi tersebut turut mempengaruhi sikap, tindakan dan seluruh perbuatan seseorang. Sebagai gejala kejiwaan, emosi memiliki sisi positif dan negatif. Sisi positif di antaranya senang, bahagia, cinta, kasih,dan sebagainya. Sedangkan sisi negatif misalnya marah, dengki, iri, cemburu, dan sebagainya.

Berdasarkan pengamatan peneliti sebelum menentukan judul Skripsi, dilakukan observasi dan wawancara dengan guru di SMPN 03 Mukomuko. Didapatkan hasil, adanya sikap siswa yang suka menyendiri, pendiam, dan dikucilkan teman serta kurang aktif didalam kelas. Hal itu disebabkan karena ketidakmampuan siswa dalam berinteraksi dan kurang mampunya mengembangkan kecerdasan emosi mereka. Ini terlihat ketika temannya asyik mengobrol di luar kelas pada saat istirahat, siswa tersebut memilih menyendiri di dalam kelas. Ada siswa yang suka marah jika ditegur. Apabila siswa tidak bisa mengenali emosi orang lain, diantaranya dia tidak mampu berempati terhadap orang lain. Pada siswa yang menyendiri karena kurang mampu mengikuti pembicaraan teman lainnya, dianataranya karena status ekonominya yang rendah atau karena tidak "Gaul”. Ada siswa yang menyendiri karena sering diejek karena wujud fisiknya. Ada yang menyendiri karena memiliki kecerdasan di bawah ratarata teman lainnya. 
Berdasarkan latar belakang tersebut, dapat dirumuskan permasalah dalam penelitian ini adalah sebagai berikut :

1. Bagaimana kecerdasan emosi siswa kelas VII SMPN 03 Mukomuko?

2. Bagaimana kemampuan bersosialisasi siswa kelas VII SMPN 03 Mukomuko?

3. Apakah ada hubungan yang positif dan signifikan antara kecerdasan emosi dengan kemampuan bersosialisasi siswa kelas VII SMPN 03 Mukomuko?

\section{Metode Penelitian}

Metode penelitian merupakan usaha untuk menemukan, mengembangkan, dan menguji suatu kebenaran pengetahuan dengan cara-cara ilmiah. Hal-hal yang perlu diperhatikan dalam penelitian adalah metode yang digunakan harus disesuaikan dengan objek dan tujuan yang akan dicapai sehingga penelitian akan berjalan dengan sistematis.

Penelitian ini menggunakan metode penelitian kuantitatif dengan analisis korelasi product moment. Populasi dalam penelitian ini sebanyak 131 siswa dan sampel penelitian sebanyak 99 siswa, alat pengumpulan data yang digunakan adalah instrumen angket.

\section{Hasil dan Pembahasan}

Pada penelitian ini terdiri dari dua variabel yaitu satu variabel bebas kecerdasan emosi(X), serta satu variabel terikat yaitu bersosialisasi (Y), dilakukan pada kelas VII SMPN 03 Mukomuko. Pada pembahasan berikut akan dideskripsikan data dari masing-masing variabel, di antaranya mean, median, modus dan standar deviasi, selain itu, akan dipaparkan juga tentang tabel deskripsi data. Berikut ini merupakan rincian dari hasil pengolahan data yang telah dilakukan dengan menggunakan bantuan program SPSS 17.

Kuesioner kecerdasan emosi terdiri dari 40 item dengan 4 pilihan jawaban yaitu 1 sampai 4 diperoleh nilai minimum 40x1=40, nilai maksimum 40x4=160, dan luas jarak sebarannya $160-40=120$ dengan standar deviasi $120: 6=20$, nilai rata-rata $120-20=100$, median $=109$, modus $=100$. 


\begin{tabular}{lllll}
\hline Kategori & Rentang Skor & Frekuensi & Persentase \\
\hline Sangat rendah40-64 & 0 & 0 & \\
Rendah & $65-88$ & 1 & $1 \%$ & \\
Sedang & $89-1125960 \%$ & \\
Tinggi & $113-136$ & 39 & $39 \%$ \\
Sangat tinggi & $137-160$ & 0 & 0 & \\
\hline
\end{tabular}

Berdasarkan perhitungan tersebut maka dapat dibuat kategorisasi data kecerdasan emosi.subjek yang memiliki kecerdasan emosi rendah sebanyak 1 orang (1\%), subjek yang memiliki kecerdasan emosi sedang sebanyak 59 orang (60\%), subjek yang memiliki kecerdasan emosi tinggi sebanyak 39 orang (39\%) . Dari data tersebut dapat diambil kesimpulan bahwa siswa kelas VII SMPN 03 Mukomuko memiliki kategorisasi kecerdasan emosi sedang.

Kuesioner bersosialisasi yang terdiri atas 32 item dengan 4 pilihan jawaban yang bergerak dari 1 sampai 4 diperoleh rentang minium adalah 32x1=32 sampai maksimum dengan $32 \times 4=128$, sehingga luas jarak sebarannya adalah $128-32=96$ dengan nilai standar deviasi $96: 6=16$, nilai rata-rata $96-16=80$, median $=87$, modus $=95$.

\section{Kategori Rentang Skor Frekuensi Persentase}

\begin{tabular}{llll}
\hline Sangat rendah & $32-51,20$ & 0 & \\
Rendah & $51,3-70,4$ & $99 \%$ \\
Sedang & $70,5-89,6$ & $4950 \%$ \\
Tinggi & $89,7-108,8 \quad 4$ & $41 \%$ \\
Sangat tinggi & $108,9-1280$ & 0
\end{tabular}

Berdasarkan perhitungan tersebut dapat dibuat kategorisasi data bersosialisasi. subjek yang memiliki bersosialisasi rendah sebanyak 9 orang (9\%) subjek yang memiliki bersosialisasi sedang sebanyak 49 orang (50\%) dan subjek yang memiliki bersosialisasi tinggi sebanyak 41 orang (41\%). Dari data tersebut dapat diambil kesimpulan bahwa siswa kelas VII SMPN 03 Mukomuko memiliki kategorisasi bersosialisasi sedang. 
Uji normalitas digunakan untuk mengetahui apakah populasi data berdistribusi normal atau tidak. Uji normalitas yang digunakan dalam penelitian ini adalah uji One Sample Kolomogrov-Smirnov Test. Dalam penelitian ini apabila signifikansi $\mathrm{p}<0,05$ atau $5 \%$ maka data-data tidak berdistribusi normal, dan sebaliknya apabila signifikasi $\mathrm{p}>0,05$ atau 5\% maka data berdistribusi normal. hasil data pada variabel kecerdasan emosi siswa kelas VII SMPN 03 Mukomuko mempunyai nilai sebesar 1.400 dengan $\mathrm{p}>0,05$, dari hasil tersebut dinyatakan bahwa sebaran kuisioner kecerdasan emosi berdistribusi normal. Variabel bersosialisasi siswa kelas VII SMPN 03 Mukomuko mempunyai nilai sebesar 1.036 dengan $\mathrm{p}>0,05$. Berdasarkan hasil tersebut dinyatakan bahwa sebaran kuesioner bersosialisasi berdistribusi normal.

Uji korelasi dengan menggunakan korelasi product moment dari Pearson dengan Statistical Package for Social Science (SPSS) versi 17. Hal ini dikarenakan data yang dihasilkan adalah data normal. hasil perhitungan korelasi antara kecerdasan emosi dan bersosialisasi, dapat dinyatakan bahwa korelasi person $\left(r_{x y}\right)$ sebesar 0,426 dengan tingkat signifikansi $0.000(\mathrm{p}<0,05)$. Jika nilai p<0,05 maka H0 ditolak, yang berarti Ha diterima.

Dapat disimpulkan bahwa terdapat hubungan yang positif dan signifikan antara kecerdasan emosi dengan kemampuan bersosialisasi dengan tingkat hubungan kuat yang artinya semakin tinggi kecerdasan emosi seseorang maka akan semakin tinggi pula kemampuan bersosialisasi, demikian juga sebaliknya semakin rendah kecerdasan emosi siswa maka semakin rendah pula kemampuan bersosialisasinya.

Berdasarkan hasil penelitian yang telah dilakukan menunjukkan bahwa tingkat kemampuan bersosialisasi siswa kelas VII SMPN 03 Mukomuko tergolong sedang. Adapun faktor yang mempengaruhi kemampuan bersosialisasi yaitu: 1) Keluarga, 2) Kematangan, 3) Status sosial ekonomi, 4) Pendidikan, 5) Kapasitas mental.

Hasil penelitian ini sejalan dengan teori Susanto (1997:12), menjelaskan sosialisasi adalah proses yang membantu individu belajar dan menyesuaikan diri. Mereka perlu mengenal bagaimana cara hidup dan melakukan bagaimana cara 
berpikir kekelompoknya, agar dia dapat berperan dan berfungsi dalam kelompoknya. Proses ini dapat berjalan serasi, dapat pula terjadi melalui peretentangan. Akan tetapi selama individu merasa memerlukan kelompoknya maka dia bersedia untuk mengadakan beberapa kompromi terhadap tuntutan kelompok.

Berdasarkan hasil penelitian yang telah dilakukan terdapat hubungan yang positif dan signifikan antara kecerdasan emosi dengan kemampuan bersosialisasi. Dari penelitian tersebut menunjukkan bahwa kecerdasan emosi siswa kelas VII SMPN 03 Mukomuko tergolong sedang. Adapun faktor yang mempengaruhi kecerdasan emosi yaitu: 1) Faktor psikologis, 2) Faktor pelatihan emosi, 3) Faktor pendidikan.

Hasil penelitian sejalan dengan teori yang diungkapkan Goleman (1995: 25), menjelaskan bahwa intelegensi emosional jauh lebih penting daripada kemampuan intelektual seseorang dalam mempengaruhi sukses hidupnya. Salah satu hal yang mendasari pandangan ini adalah bahwa gejolak perasaan sangat mempengaruhi proses berpikir. Misalnya, ketika individu tengah berada dalam kemarahan, konsentrasinya mudah terganggu sehingga pengambilan keputusannya pun mengalami hambatan. Jadi, sekalipun seseorang memiliki tingkat pendidikan tinggi namun jika tidak mampu mengendalikan emosinya dengan baik, cenderung mudah mengalami hambatan dalam berinteraksi sosial. Akibatnya, dia akan mengalami banyak kesulitan dalam pekerjaannya.

Berdasarkan hasil uji korelasi antara kecerdasan emosi dengan kemampuan bersosialisasi siswa menunjukkan bahwa terdapat hubungan yang positif dan signifikan antara kecerdasan emosi dengan kemampuan bersosialisasi siswa kelas VII SMPN 03 Mukomuko. Pada hasil korelasi tersebut dapat disimpulkan bahwa kecerdasan emosi memiliki hubungan atau korelasi dengan kemampuan bersosialisasi, dan hubungan tersebut dalam tingkat hubungan yang sedang dengan $r_{x y}=0,426$. Hal tersebut dapat diketahui bahwa kecerdasan emosi merupakan salah satu faktor yang mempengaruhi dan mempunyai hubungan dalam memiliki kemampuan bersosialisasi siswa. Maka dari itu kecerdasan emosi 
merupakan hal yang sangat berpengaruh terhadap kemampuan bersosialisasi siswa, dengan memiliki kecerdasan emosi yang baik maka akan meningkatkan kemampuan bersosialisasi siswa dan mampu menjalin hubungan yang baik dengan siswa lain.

Penelitian ini senada dengan penelitian yang dilakukan oleh Mawarti (2015), yang menyatakan bahwa semakin tinggi kecerdasan emosional siswa semakin tinggi interaksi sosialnya. Penelitian lainnya yang dilakukan oleh Wardani (2012), yang menyatakan terdapat hubungan yang positif dan signifikan antara kecerdaan emosional dengan penerimaan teman sebaya.

Berdasarkan hasil penelitian yang telah dilakukan tersebut dapat disimpulkan bahwa terdapat hubungan yang positif dan signifikan antara kecerdasan emosi dengan kemampuan bersosialisasi siswa. Semakin tinggi kecerdasan emosi siswa akan diikuti oleh semakin tinggi pula kemampuan bersosialisasi siswa. Demikian sebaliknya, semakin rendah kecerdasan emosi siswa maka akan semakin rendah pula kemampuan bersosialisasinya.

\section{Kesimpulan}

Berdasarkan hasil analisis data yang telah dilakukan dapat ditarik kesimpulan bahwa :

1. Tingkat kecerdasan emosi siswa kelas VII SMPN 03 Mukomuko tergolong sedang.

2. Tingkat kemampuan bersosialisasi siswa kelas VII SMPN 03 Mukomuko tergolong sedang.

3. Terdapat hubungan yang positif dan signifikan antara kecerdasan emosi dengan kemampuan bersosialisasi siswa kelas VII SMPN 03 Mukomuko diperoleh $r_{x y}=0,426$ dengan tingkat hubungan sedang dan taraf signifikan $0,000(\mathrm{p}<0,05)$ maka H0 ditolak dan Ha diterima. 


\section{Daftar Pustaka}

Susanto, A. S.(1997). Pengantar Sosiologi dan Perubahan Sosial. Jakarta : Bina Cipta.

Danim, S. (2010). Profesi Kependudukan. Bandung:Alfabeta.

Goleman, D. (1995). Emotional Intelligence. Jakarta: Pustaka Utama.

Mawarti, F. (2015). Hubungan kecerdasan emosional dengan interaksi sosial siswa. (Skripsi tidak dipublikasikan). Program studi Bimbingan dan Konseling FKIP Universitas Nusantara PGRI Kediri. Diunduhdari http://simki.Ip2m.unpkediri.ac.id/mahasiswa/file_artikel/2015/11.1.01.01.01 29.Pdf. Tanggal 10 Januari 2018.

Munandar, U. (2009). Pengembangan Kreativitas Anak Berbakat. Jakarta :Rineka Cipta.

Mutammimah. (2014). Hubungan Konsep Diri dan Kecerdasan Emosi dengan Kemampuan Penyesuaian Diri Remaja. Jurnal Psikologi Indonesia. 3 (1). Hal 42-51.

Nasution, F. (2003). Pengaruh Persepsi Agama dan Kecerdasan Emosional terhadap Konsep Diri Siswa. Jurnal Ilmu Pendidikan. 10(2). Hal 1-8.

Seha, K. N. (2013). Perbedaan Kemampuan Bersosialisasi ditinjau dari mata pencaharian orang tua siswa. Jurnal Ekonomi IKIP Veteran Semarang. 1 (1). Hal 29-37.

Sukardi. (2008). Metodologi Penelitian Pendidikan Kompetensi dan Praktiknya. Jakarta: Bumi Aksara.

Wardani, F. E. (2012). Hubungan antara kecerdasan emosional dengan penerimaan teman sebaya pada siswa Akselerasi. (Skripsi tidak dipublikasikan).Fakultas Psikologi Universitas Islam Negeri Sultan Syarief Kasim Riau, Pekanbaru. Diunduhdarihttp://repository.uinsuska.ac.id/3913/1/2013_201301PSI.pdf. Tanggal 10 Januari 2018. 